\title{
First Record of Scirtidae (Coleoptera) Associated with Decaying Carcasses in the Neotropical Region
}

\author{
Rodrigo Cesar Azevedo Pereira Farias ${ }^{\circledR}{ }^{\bowtie}$, Daniel Dal-Bó ${ }^{1}$, Wellington Emanuel dos Santos ${ }^{1}$, \\ Antonio José Creão-Duarte1 \& Patricia Jacqueline Thyssen²
}

1. Universidade Federal da Paraíba, e-mail: rodrigoento@gmail.com (Autor para correspondência ${ }^{\bowtie}$ ), danieldb@hotmail.com, well-bio@hotmail.com, creaoduarte@yahoo.com.br. 2. Universidade Federal de Pelotas, e-mail: thyssenpj@yahoo.com.br.

\section{EntomoBrasilis 6(2): 171-172 (2013)}

Abstract. During a two-year study on the insect fauna associated with pig carcasses in an Atlantic forest remnant in João Pessoa, state of Paraíba, Brazil, 127 adult Scirtes sp. were collected. This is the first record of specimens of the family Scirtidae associated with carcasses in the Neotropical region.

Keywords: Atlantic forest; Forensic entomology; Marsh beetles.

\section{Primeiro Registro de Scirtidae (Coleoptera) Associado a Carcaças em Decomposição na Região Neotropical}

Resumo. Durante um estudo de dois anos da entomofauna associada a carcaças de suínos em um remanescente de Mata Atlântica em João Pessoa, PB, Brasil, foram coletados 127 indivíduos de Scirtes sp. Este é o primeiro registro de exemplares da família Scirtidae associados a carcaças na região Neotropical.

Palavras-Chave: Besouros Scirtes; Entomologia forense; Mata Atlântica.

$\sqrt{n}$ The family Scirtidae comprises around 800 species described in 35 genera, being Scirtes the second richest genus, with 250 species occurring mainly in temperate regions (Young 2002; Yoshitomi 2009; Slipinski et al. 2011). Recent studies on taxonomic review have focused only on the eastern species of the world (Yoshiтomi 2009; Yoshiтomi \& Ruta 2010), so that the western ones, especially of the Neotropical region, are poorly known.

Too little is known about the biology of Scirtidae. Larvae grow on soggy environments (streams, lakes, ponds and swamps), tolerating significant fluctuations of the water level, where they feed by filtering organic matter (MARINONI et al. 2001; Young 2002). Adults of some species can be predators, living under the vegetation and feeding on microinvertebrates (MUONA \& RUTANEN 1994). Their association with carrion is unknown, being this the first report of Scirtidae associated with decaying animal matter.

The study took place in an Atlantic forest remnant in João Pessoa, state of Paraíba, Brazil (7 $8^{\circ} 20^{\prime \prime}$ S; $\left.34^{\circ} 51^{\prime} 34^{\prime \prime W}\right)$. The area is known as "Mata do Buraquinho", which is crossed by the Jaguaribe river, where is dammed and forms the "Açude do Buraquinho", located about $200 \mathrm{~m}$ away from the study site. Samplings took place in four periods: two in 2009 (March and September) and two in 2010 (March and August) corresponding, in each year, the first sampling to the dry season and the second one to the rainy season. On both periods, two fresh pig (Sus scrofa Linnaeus) carcasses (about $12 \mathrm{~kg}$ each) were exposed to decay in order to attract insects. Each carcass was placed in an iron cage covered by a tent-shaped trap, modified from the one created by SHANNON (1939), surrounded by eight pitfall traps. Insects were collected daily, with insect net the ones inside the tents, and with sieves and forceps those from the pitfalls. In the last sampling period (August 2010), a third set of traps were placed, following the same sampling methods of the other ones, but without carcass, with the aim of verifying the real attractiveness of the carcasses. All insects collected were mounted and deposited in "Coleção Entomológica do Departamento de Sistemática e Ecologia” of "Universidade Federal da Paraíba" (DSEC/UFPB). The study was authorized by the Ethic Commission for the Usage of Animals of the same institution (CEUA/UFPB).

Amongst Coleoptera, 127 adult specimens of Scirtidae were collected, all belonging to Scirtes sp., identified with the keys by Young (2002), and confirmed by the specialist Dr. Rafal Ruta (Wroclaw University, Poland). The species showed the highest abundance among beetles collected from the carcasses, and not a single specimen was collected in the third set of traps placed in the last sampling period. The Scirtidae specimens were more abundant in the dry seasons (77.9\%), when compared to the wet ones (22.1\%), and $92 \%$ of them were collected actively with insect net inside the tents.

The decomposition process lasted eight days, and five stages could be perceived: fresh, bloated, active decay, advanced decay and skeletonization. Specimens of Scirtes sp. were captured on the carcasses following the same colonization pattern showed by members of the families Staphylinidae and Histeridae: the majority were collected during the bloated (33.9\%), active decay (20.5\%) and advanced decay (33.1\%) stages, when there was great abundance of Diptera larvae. Therefore, it is possible to presume that Scirtes sp. adults also act as predators on the carcasses.

Agência(s) de Financiamento: CAPES 
The presence of Scirtes sp. in this study represents the first record of the family Scirtidae associated with carcasses in the Neotropical region. Though the family is not included in the widely used classification of forensically important Coleoptera by SMith (1986), due to its abundance, seasonality and occurrence pattern on the carcasses, the family showed itself relevant concerning to this aspect. Future studies are required to confirm their role on carcasses and their possible forensic utility. Besides that, since each region has its peculiar carrion insect fauna (Pujol-Luz et al. 2008; Santos et al. 2012; Silva \& SAntos et al. 2012), the remarkable presence of Scirtidae reinforces the need of regional studies about the composition of insects associated with carcasses throughout Brazil.

\section{ACKNOWLEDGEMENTS}

The authors are grateful to Coordenação de Aperfeiçoamento de Pessoal de Nível Superior (CAPES) for providing them scholarships.

\section{REFERENCES}

Marinoni, R.C., N.G. Ganho, M.L. Monné \& J.R.M. Mermudes, 2001. Hábitos Alimentares em Coleoptera (Insecta). Ribeirão Preto, Holos Editora, 63p.

Muona, J. \& I. Rutanen, 1994. The short-term impact of fire on the beetles fauna in boreal coniferous forest. Annales Zoologici Fennici, 31: 109-121.

Pujol-Luz, J.R.; L.C. Arantes \& R. Constantino, 2008. Cem anos da Entomologia Forense no Brasil (1908-2008). Revista Brasileira de Entomologia, 52: 485-492.
Santos, W.E., A.C.F. Alves \& A.J. Creão-Duarte, 2012. Dermestes peruvianus Laporte (Coleoptera, Dermestidae): primeiro registro para o Nordeste do Brasil. EntomoBrasilis, 5: 253254.

Shannon, R.C., 1939. Methods for collecting and feeding mosquitoes in jungle yellow fever studies. American Journal of Tropical Medicine and Hygiene, 19: 131-140.

Silva, R.C. \& W.E. Santos, 2012. Fauna de Coleoptera associada a carcaças de coelhos expostas em uma área urbana no Sul do Brasil. EntomoBrasilis, 5: 185-189.

Slipinski, S.A., R.A.B. Leschen \& J.F. Lawrence, 2011. Order Coleoptera Linnaeus, 1758. In: Zhang, Z.-Q. (Ed.) Animal biodiversity: An outline of higher-level classification and survey of taxonomic richness. Zootaxa, 3148: 203-208.

Smith, K.G.V., 1986. A Manual of Forensic Entomology. Ithaca, Cornell University Press, 205p.

Yoshitomi, H.\&R. Ruta, 2010. Revision of theScirtesflavoguttatus species-group (Coleoptera: Scirtidae: Scirtinae). Zootaxa, 2467: 1-74.

Yoshitomi, H. 2009. The Scirtes (Coleoptera: Scirtidae: Scirtinae) of Micronesia. Zootaxa, 1974: 1-16.

Young, D.K., 2002. Scirtidae Fleming 1821, p. 87-89. In: Arnett, R.H., M.C Thomas, P.E. Skelley \& J.H. Frank (Eds.). American Beetles, Volume 2: Polyphaga: Scarabaeoidea through Curculionoidea. Boca Raton, CRC Press, 861p.

Recebido em: 28/12/2012

Aceito em: 14/o3/2013

\section{Como citar este artigo:}

Farias, R.C.A.P., D. Dal-Bó, W.E. Santos, A.J. Creão-Duarte \& P.J. Thyssen, 2013. First Record of Scirtidae (Coleoptera) Associated with Decaying Carcasses in the Neotropical Region. EntomoBrasilis, 6(2): 171-172.

Acessível em: http://www.periodico.ebras.bio.br/ojs/index.php/ebras/article/view/311. doi:10.12741/ebrasilis.v6i2.311 